
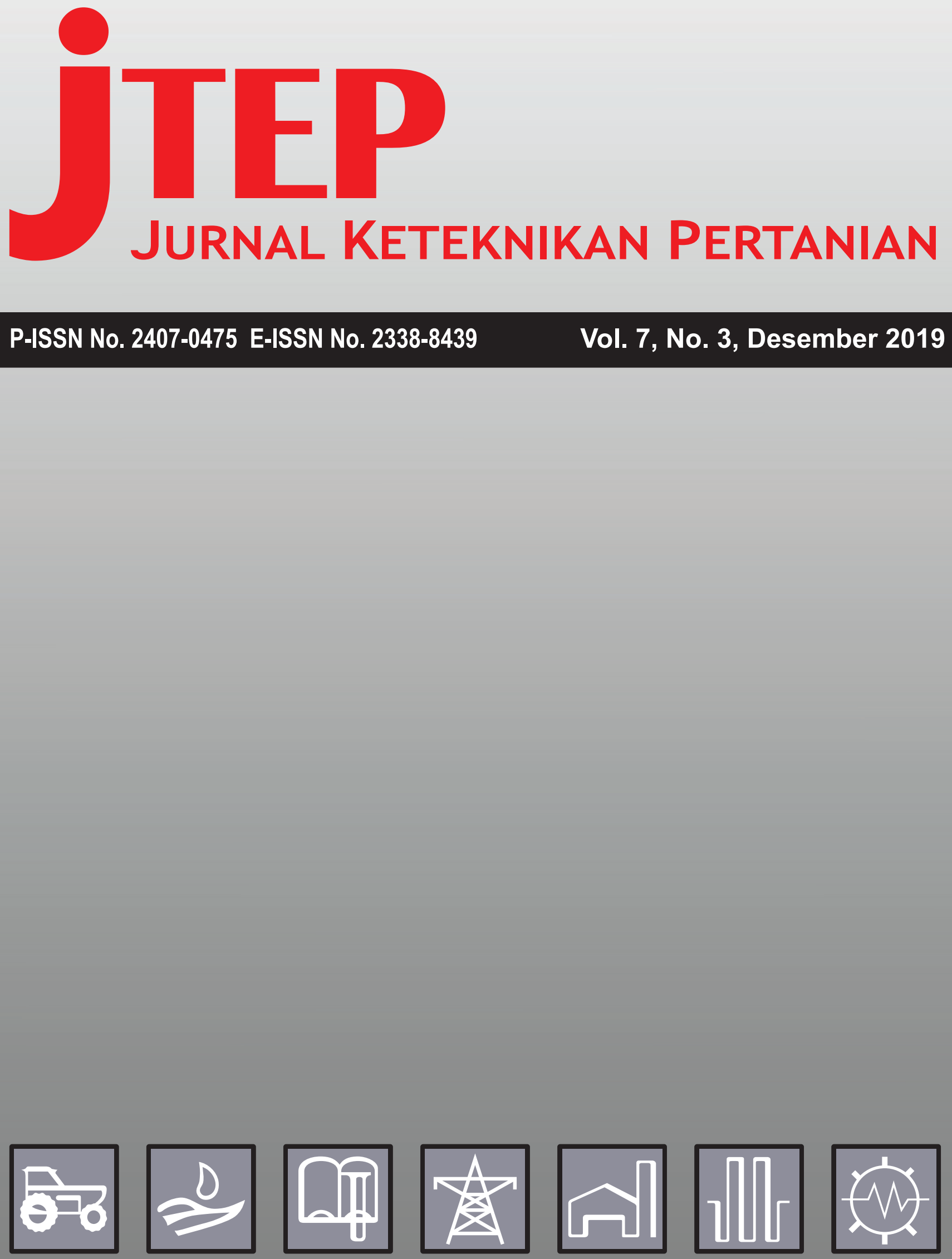

Publikasi Resmi
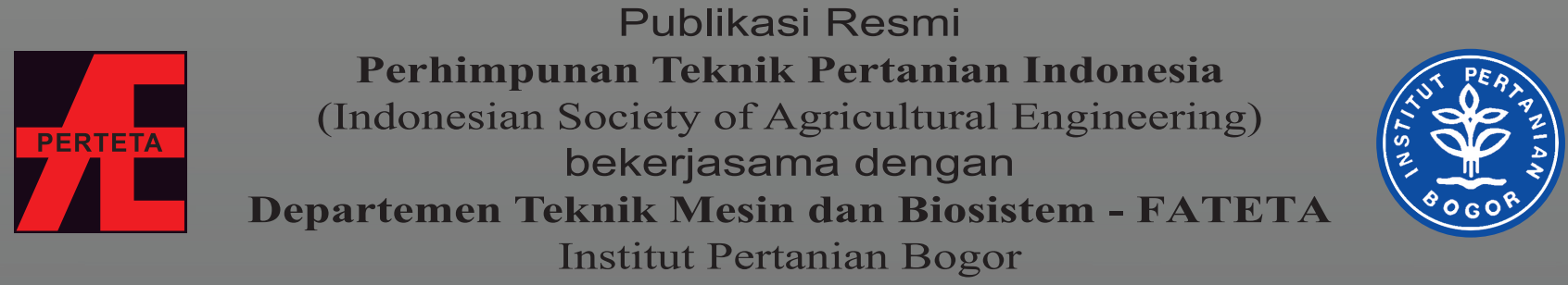


\section{jteP JURnal Keteknikan PERTANIAN}

Vol. 7, No. 3. Desember 2019

Jurnal Keteknikan Pertanian (JTEP) terakreditasi berdasarkan SK Dirjen Penguatan Riset dan Pengembangan Kementerian Ristek Dikti Nomor I/E/KPT/2015 tanggal 21 September 2015. Selain itu, JTEP juga telah terdaftar pada Crossref dan telah memiliki Digital Object Identifier (DOI) dan telah terindeks pada ISJD, IPI, Google Scholar dan DOAJ. JTEP terbit tiga kali setahun yaitu bulan April, Agustus dan Desember, Jurnal berkala ilmiah ini berkiprah dalam pengembangan ilmu keteknikan untuk pertanian tropika dan lingkungan hayati. Penulis makalah tidak dibatasi pada anggota PERTETA tetapi terbuka bagi masyarakat umum. Lingkup makalah, antara lain meliputi teknik sumberdaya lahan dan air, alat dan mesin budidaya pertanian, lingkungan dan bangunan pertanian, energi alternatif dan elektrifikasi, ergonomika dan elektronika pertanian, teknik pengolahan pangan dan hasil pertanian, manajemen dan sistem informasi pertanian. Makalah dikelompokkan dalam invited paper yang menyajikan isu aktual nasional dan internasional, review perkembangan penelitian, atau penerapan ilmu dan teknologi, technical paper hasil penelitian, penerapan, atau diseminasi, serta research methodology berkaitan pengembangan modul, metode, prosedur, program aplikasi, dan lain sebagainya. Penulisan naskah harus mengikuti panduan penulisan seperti tercantum pada website dan naskah dikirim secara elektronik (online submission) melalui http://journal.ipb.ac.id/index.php/jtep.

\section{Penanggungjawab:}

Ketua Departemen Teknik Mesin dan Biosistem, Fakultas Teknologi Pertanian,IPB

Ketua Perhimpunan Teknik Pertanian Indonesia

\section{Dewan Redaksi:}

Ketua : Yohanes Aris Purwanto (Scopus ID: 6506369700, IPB University)

Anggota : Abdul Hamid Adom (Scopus ID: 6506600412, University Malaysia Perlis)

(editorial Addy Wahyudie (Scopus ID: 35306119500, United Arab Emirates University)

board) Budi Indra Setiawan (Scopus ID: 55574122266, IPB University)

Balasuriya M.S. Jinendra (Scopus ID: 30467710700 , University of Ruhuna)

Bambang Purwantana (Scopus ID: 6506901423, Universitas Gadjah Mada)

Bambang Susilo (Scopus ID: 54418036400, Universitas Brawijaya)

Daniel Saputera (Scopus ID: 6507392012, Universitas Sriwjaya)

Han Shuqing (Scopus ID: 55039915600, China Agricultural University)

Hiroshi Shimizu (Scopus ID: 7404366016, Kyoto University)

I Made Anom Sutrisna Wijaya (Scopus ID: 56530783200, Universitas Udayana)

Agus Arif Munawar (Scopus ID: 56515099300, Universitas Syahkuala)

Armansyah H. Tambunan (Scopus ID: 57196349366, IPB University)

Kudang Boro Seminar (Scopus ID: 54897890200, IPB University)

M. Rahman (Scopus ID: 7404134933, Bangladesh Agricultural University)

Machmud Achmad (Scopus ID: 57191342583, Universitas Hasanuddin)

Muhammad Makky (Scopus ID: 55630259900, Universitas Andalas)

Muhammad Yulianto (Scopus ID: 54407688300, IPB University \& Waseda University)

Nanik Purwanti (Scopus ID: 23101232200, IPB University \& Teagasc Food Research Center Irlandia)

Pastor P. Garcia (Scopus ID: 57188872339 , Visayas State University)

Rosnah Shamsudin (Scopus ID: 6507783529, Universitas Putra Malaysia)

Salengke (Scopus ID: 6507093353, Universitas Hasanuddin)

Sate Sampattagul (Scopus ID: 7801640861, Chiang Mai University)

Subramaniam Sathivel (Scopus ID: 6602242315, Louisiana State University)

Shinichiro Kuroki (Scopus ID: 57052393500 , Kobe University)

Siswoyo Soekarno (Scopus ID: 57200222075 , Universitas Jember)

Tetsuya Araki (Scopus ID: 55628028600, The University of Tokyo)

Tusan Park (Scopus ID: 57202780408, Kyungpook National University) 


\section{Redaksi Pelaksana:}

Ketua : Usman Ahmad (Scopus ID: 55947981500, IPB University)

Sekretaris : Lenny Saulia (Scopus ID: 16744818700, IPB University)

Bendahara : Dyah Wulandani (Scopus ID: 1883926600, IPB University)

Anggota : Satyanto Krido Saptomo (Scopus ID: 6507219391, IPB University)

Slamet Widodo (Scopus ID: 22636442900, IPB University)

Liyantono (Scopus ID: 54906200300, IPB University)

Leopold Oscar Nelwan (Scopus ID: 56088768900, IPB University)

I Wayan Astika (Scopus ID: 43461110500, IPB University)

Agus Ghautsun Niam (Scopus ID: 57205687481, IPB University)

Administrasi : Diana Nursolehat (IPB University)

Penerbit: Perhimpunan Teknik Pertanian Indonesia (PERTETA) bekerjasama dengan Departemen Teknik Mesin dan Biosistem, Institut Pertanian Bogor.

Alamat: Jurnal Keteknikan Pertanian, Departemen Teknik Mesin dan Biosistem, Fakultas Teknologi Pertanian, Kampus Institut Pertanian Bogor, Bogor 16680.

Telp. 0251-8624 503, Fax 0251-8623 026,

E-mail: jtep@ipb.ac.id atau jurnaltep@yahoo.com

Website: web.ipb.ac.id/ jtep atau http://journal.ipb.ac.id/index.php/jtep

Rekening: BRI, KCP-IPB, No.0595-01-003461-50-9 a/n: Jurnal Keteknikan Pertanian

Percetakan: PT. Binakerta Makmur Saputra, Jakarta 


\section{Ucapan Terima Kasih}

Redaksi Jurnal Keteknikan Pertanian mengucapkan terima kasih kepada para Mitra Bebestari yang telah menelaah (me-review) Naskah pada penerbitan Vol. 7 No. 3 Desember 2019. Ucapan terima kasih disampaikan kepada: Prof.Dr.Ir. Bambang Purwantana, M.Agr (Fakultas Teknologi Pertanian, Universitas Gadjah Mada), Dr.Ir. Nugroho Tri Waskito, MP (Fakultas Pertanian dan Peternakan, Universitas Muhammadiyah Malang), Dr. Ardiansyah, S.TP, M.Si (Fakultas Pertanian, Universitas Jenderal Soedirman), Dr. Ridwan Rahmat (Balai Penelitian Pasca Panen Cimanggu), Prof.Dr.Ir. Budi Indra Setiawan, M.Agr. (Departemen Teknik Sipil dan Lingkungan, Fakultas Teknologi Pertanian, Institut Pertanian Bogor), Prof.Dr.Ir. Sutrisno M.Agr (Departemen Teknik Mesin dan Biosistem, Fakultas Teknologi Pertanian, Institut Pertanian Bogor), Dr.Ir. Wawan Hermawan, MS (Departemen Teknik Mesin dan Biosistem, Fakultas Teknologi Pertanian, Institut Pertanian Bogor), Dr.Ir. Dyah Wulandani, MSi (Departemen Teknik Mesin dan Biosistem, Fakultas Teknologi Pertanian, Institut Pertanian Bogor), Dr. Slamet Widodo, S.TP, M.Sc (Departemen Teknik Mesin dan Biosistem, Fakultas Teknologi Pertanian, Institut Pertanian Bogor), Dr. Liyantono, S.TP, M.Agr (Departemen Teknik Mesin dan Biosistem, Fakultas Teknologi Pertanian, Institut Pertanian Bogor) 


\title{
Desain dan Uji Kinerja Alat Pengering Hybrid dengan Efek Cerobong Tipe Tumpukan untuk Pengeringan Biji Kopi Arabika
}

\author{
Design and Performance Hybrid Drying with Chimney Effect for Drying Arabica Beans \\ Coffee
}

\author{
Irwansyah, Departemen Teknik Mesin dan Biosistem, Institut Pertanian Bogor. \\ Email: s.irwan24@ymail.com \\ Leopold Oscar Nelwan, Departemen Teknik Mesin dan Biosistem, Institut Pertanian Bogor. \\ Email: Ionelwan@yahoo.com \\ Dyah Wulandani, Departemen Teknik Mesin dan Biosistem, Institut Pertanian Bogor.
} Email: dwulandani@yahoo.com

\begin{abstract}
Artificial drying method for arabica coffee beans requires a large consumption of electrical energy. Electricity is needed to rotate the blower which functions to circulate hot air to the dryer so that it can evaporate some of the water contained in the coffee beans. Most of the arabica coffee producing areas in Aceh province have not been reached by the electricity network so the use of artificial dryers cannot be used. To overcome this obstacle, the air flow circulation system with chimney effect can be used to drain dry air. The aim of this research is to design a chimney effect hybrid dryer which is heat source from solar and biomass energy, to test the performance of the dryer and compare it with the sun drying method. Parameters observed were temperature, moisture content and specific energy consumption of solar radiation and biomass. Dryer capacity is $5 \mathrm{~kg}$ of arabica coffee beans. The results showed that the chimney effect hybrid dryer can be used to dry $5 \mathrm{~kg}$ of coffee beans. The drying show that drying temperature on the dryer chamber ranged between $37.3-60.9^{\circ} \mathrm{C}$. To reduce the moisture content of coffee beans from 52.5 to $12.8 \% \mathrm{bb}$, it was take 16-17 hours, while the sun drying method takes up to 46 hours (6 days). The total specific energy consumption of hybrid dryer was $57.1 \mathrm{MJ} / \mathrm{kg}$ of water vapor, while the specific energy consumption of the drying method was $59.4 \mathrm{MJ} / \mathrm{kg}$ of water vapor.
\end{abstract}

Keywords: arabica coffee beans, chimney effect, hybrid dryer, solar and biomass energy

\begin{abstract}
Abstrak
Metode pengeringan buatan untuk biji kopi arabika membutuhkan konsumsi energi listrik yang besar. Listrik diperlukan untuk menggerakan blower yang berfungsi untuk mensirkulasikan udara panas ke bak pengering sehingga dapat menguapkan sejumlah air yang terkandung pada biji kopi. Sebagian besar daerah penghasil kopi arabika di provinsi Aceh belum terjangkau jaringan listrik sehingga pemakaian alat pengering berenergi listrik tidak dapat digunakan. Untuk mengatasi kendala ini, sistem sirkulasi pengaliran udara dengan efek cerobong dapat digunakan untuk mengalirkan udara kering. Penelitian ini bertujuan untuk merancang alat pengering hybrid dengan efek cerobong skala percobaan yang bersumber panas dari energi surya dan biomassa, menguji kinerja pengering serta membandingkannya dengan metode penjemuran. Parameter yang diamati antara lain suhu, kadar air bahan dan konsumsi energi spesifik. Hasil penelitian menunjukkan bahwa alat pengering hybrid efek cerobong dapat digunakan untuk mengeringkan $5 \mathrm{~kg}$ biji kopi. Suhu pada ruang pengering berkisar $37.3-60.9^{\circ} \mathrm{C}$, mampu mengurangi kadar air biji kopi dari $52.5 \% \mathrm{bb}$ hingga $12.8 \% \mathrm{bb}$ selama $16-17$ jam, sedangkan metode pengeringan matahari membutuhkan waktu hingga 46 jam (6 hari). Total konsumsi energi spesifik alat pengering hybrid adalah $57.3 \mathrm{MJ} / \mathrm{kg}$ uap air, sedangkan konsumsi energi spesifik dari metode pengeringan adalah $59.4 \mathrm{MJ} / \mathrm{kg}$ uap air.
\end{abstract}

Kata Kunci: biji kopi arabika, efek cerobong, energi surya dan biomassa, pengering hybrid 


\section{Pendahuluan}

Provinsi Aceh merupakan salah satu sentra penghasil kopi arabika dikenal dengan nama kopi arabika Gayo. Kopi arabika tumbuh subur di Dataran Tinggi Gayo khususnya di tiga Kabupaten yakni, Aceh Tengah, Bener Meriah 45 ribu hektar, dan Gayo Lues (BPS Provinsi Aceh 2012). Pengolahan pasca panen kopi arabika dilakukan secara pengolahan basah, meliputi tahapan panen, sortasi buah, pengupasan kulit buah, fermentasi pencucian, pengeringan, pengupasan kulit cangkang, sortasi biji serta pengemasan dan penyimpanan (Ditjenbun 2012). Tahapan proses pengolahan biji kopi yang sangat penting adalah proses pengeringan karena hasil dari capaian akan menentukan kualitas biji kopi yang dihasilkan, termasuk mengolah biji kopi menjadi kopi bubuk (Hamni et al 2014). Proses pengeringan adalah proses mengurangi kadar air dari produk sampai pada tingkat tertentu, sehingga dapat mencegah pembusukan dan aman disimpan dalam jangka waktu yang lama (Ekechukwu dan Norton 1999). Petani kopi arabika mengeringkan kopi dengan metode penjemuran di bawah sinar matahari, dimana biji kopi diletakkan di atas plastik terpal, di lantai penjemuran dan para-para atau tampahan. Kendala metode penjemuran yaitu, waktu pengeringan yang lama, membutuhkan lokasi yang luas, dan kondisi cuaca yang tidak menentu (mendung atau hujan) di Dataran Tinggi Gayo. Hal ini akan memperlambat proses pengeringan sehingga menyebabkan kerusakan pada biji kopi akibat aktivitas mikro organisme dan mutu biji kopi menjadi rendah. Pada industri rumah tangga biji kopi dikeringkan dengan pengering mekanis tipe bak bersumber panas dari tungku biomassa dan gas. Proses distribusi dan sirkulasi udara panas bak pengering digunakan blower untuk menguapkan air dari produk selama proses pengeringan. Penggunaan blower secara intensif, biaya operasionalnya lebih besar karena dibutuhkan tenaga listrik sebagai penggerak. Peningkatan harga energi fosil menjadi masalah tersendiri dalam penerapan alat pengering mekanis bagi industri rumah tangga dan petani. Disisi lain sebagian besar daerah penghasil kopi arabika di provinsi Aceh belum terjangkau jaringan listrik sehingga pemakaian pengering mekanis dengan sirkulasi udara menggunakan blower tidak dapat diaplikasikan. Upaya mengatasi kendala di atas telah banyak dikembangkan alat pengering buatan bersumber panas dari energi surya menggunakan kolektor surya tipe pelat datar dengan sistem pengaliran udara secara alami atau metode efek cerobong untuk mengeringkan produk pertanian. Kelebihan sistem ini, waktu pengeringan relatif lebih cepat dan mudah diterapkan oleh petani (Pangavhane et al. (2002); Rushon et al. (2009); dan Al-Neama dan Farkas (2016). Prinsip aliran fluida alami dengan efek cerobong merupakan pengganti blower yang berfungsi untuk mensirkulasikan udara panas pada ruang pengering. Efek cerobong merupakan fenomena pergerakan fluida secara pindah panas konveksi alami akibat perbedaan suhu (Holman 1990). Laju aliran pada efek cerobong dapat dinyatakan sebagai:
$\dot{m}=C A \sqrt{2 g h \frac{T_{i}-T_{o}}{T_{i}}}$

Dimana $\mathrm{m}$ adalah laju aliran, $\mathrm{C}$ koefisien discharge, g percepatan gravitasi $\left(\mathrm{m} / \mathrm{s}^{2}\right)$, T adalah suhu dalam cerobong $(K)$ dan To adalah suhu lingkungan $(K)$.

Seperti yang telah dilaporkan Mwithiga dan Kigo (2006) untuk pengeringan biji kopi arabika menggunakan kolektor surya plat datar dengan sistem tracking memanfaatkan sumber panas dari energi surya. Sistem kerja pengering ini, udara panas dari penyerapan radiasi surya oleh kolektor surya dialirkan secara konveksi alami ke ruang pengering untuk mengeringkan biji kopi arabika dari kadar air $54.8 \%$ bb hingga $13 \%$ bb, kisaran suhu pengeringan $37-70.4^{\circ} \mathrm{C}$ dan waktu pengeringan selama 2 hari, sedangkan metode penjemuran membutuhkan waktu hingga 5-7 hari. Kendala dari sistem pengering ini adalah radiasi surya berfluktuatif dipengaruhi oleh perubahan cuaca (mendung dan hujan) sehingga menurunkan penyerapan panas dari kolektor surya, dan berdampak terhadap kecilnya suhu ruang pengering sehingga mengakibatkan terhambatnya proses pengeringan.

Untuk mengatasi kelemahan tersebut Madhlopa dan Ngwalo (2007) telah mendesain alat pengering hybrid berenergi surya dan biomassa untuk mengeringkan buah nanas dengan sistem pengaliran udara secara efek cerobong (konveksi alami). Sistem pengering kombinasi dapat dioperasikan tanpa mengkhawatirkan masalah perubahan cuaca dan dapat digunakan pada malam hari. Komponen dari alat pengering tersebut terdiri dari kolektor surya, batu penyimpanan panas, plenum, ruang pengering, outlet ruang pengering berupa cerobong, dan tungku pembakaran, dimana penataan kolektor surya dan tungku dilakukan secara seri. Tujuan penelitian ini melakukan pengembangan desain dan uji kinerja pengering hybrid dengan efek cerobong tipe tumpukan untuk mengeringkan biji kopi arabika dengan konfigurasi aliran udara yang terpisah antara heat exchanger dan kolektor surya.

\section{Metode Penelitian}

\section{Waktu dan Tempat}

Penelitian dilaksanakan pada bulan Juni 2017 sampai April 2018 di Laboratorium Lapangan Siswandhi Soepardjo dan Laboratorium Energi dan Elektrifikasi Pertanian, Departemen Teknik Mesin dan Biosistem, Fakultas Teknologi Pertanian Institut Pertanian Bogor.

\section{Peralatan dan Bahan}

Peralatan pembuatan konstruksi alat pengering antara lain adalah mesin gerinda duduk dan tangan, mesin bor duduk dan tangan, mesin las listrik dan LPG, serta peralatan perbengkelan lainnya. Bahan yang digunakan pada percobaan adalah biji kopi arabika dari perkebunan kopi Kabupaten Bener Meuriah provinsi Aceh dan biomassa berupa kayu rambutan sebagai bahan bakar pengujian. 


\section{Pembuatan Model alat pengering}

Pembuatan model alat pengering hybrid terdiri dari unit bak pengering, kolektor surya plat datar, tungku pembakaran dan heat exchanger, dan cerobong outlet ruang pengering. Komponen pengering hybrid dapat dilihat pada Gambar 1.

Detail tiap komponen alat pengering hybrid dengan efek cerobong dijabarkan sebagai berikut:

1. Bak pengering berfungsi sebagai tempat pengering biji kopi dan terhubung dengan ruang pengering. Dimensi bak pengering $0.5 \mathrm{~m} \times 0.3 \mathrm{~m} \times 0.14 \mathrm{~m}$ dan dimensi ruang pengering $0.5 \mathrm{~m} \times 0.3 \mathrm{~m} \times 0.4 \mathrm{~m}$. Pada alas bak pengering dipasangkan mesh dengan dimensi lubang berdiameter $4 \mathrm{~mm}$ berfungsi untuk menahan produk sekaligus sebagai saluran udara dari plenum ke bahan yang dikeringkan. Di bawah ruang pengering terdapat ruang plenum berdimensi $0.5 \mathrm{~m} \times 0.3 \mathrm{~m} \times 0.15 \mathrm{~m}$ yang berfungsi sebagai penyeragaman aliran udara panas dari kolektor dan penukar panas. Dinding ruang pengering dan bagian bawah dipasangkan insulasi berbahan glasswool yang berfungsi sebagai insulator.

2. Kolektor surya plat datar berfungsi mengumpulkan radiasi surya dalam bentuk panas. Kolektor surya berdimensi $1 \mathrm{~m} \times 0.5 \mathrm{~m} \times 0.14 \mathrm{~m}$ dan pada bagian depan kolektor terdapat saluran inlet udara lingkungan berdiameter $0.036 \mathrm{~m}$ sebanyak lima buah. Saluran outlet kolektor terhubung dengan ruang plenum pada ruang pengering dengan panjang $0.5 \mathrm{~m}$ dan diameter $0.076 \mathrm{~m}$. Plat absorber berfungsi untuk menyerap panas surya berbahan besi dengan ketebalan $2 \mathrm{~mm}$ dan dicat warna hitam. Kemiringan permukaan kolektor surya $9^{0}$, dan setiap dinding bagian luar dan bawah kolektor dipasangkan insulasi berbahan glasswoll setebal $40 \mathrm{~mm}$. Plat absorber merupakan bagian dari kolektor yang berfungsi untuk menyerap panas surya. Absorber berbahan besi berwarna hitam dengan ketebalan $2 \mathrm{~mm}$. Penutup kolektor terbuat dari arkrilik dengan dan jarak antara plat absorber dan penutup kolektor $0.09 \mathrm{~mm}$.

3. Tungku pembakaran, berfungsi untuk menyuplai panas ke ruang pengering melalui Heat exchanger dari hasil pembakaran kayu. Dimensi tungku $0.42 \mathrm{~m}$ x $0.42 \mathrm{~m} \times 0.35 \mathrm{~m}$, dan dimensi hoper tungku $0.2 \mathrm{~m} \times$ $0.19 \mathrm{~m}$, setiap dinding tungku diinsulasi dengan batu bata dengan ketebalan $80 \mathrm{~mm}$.

4. Heat exchanger menggunakan tipe shell and tube tipe aliran cross flow, berdimensi $0.5 \mathrm{~m} \times 0.3 \mathrm{~m} \times 1 \mathrm{~m}$. Dinding heat exchanger di insulasi dengan glasswoll setebal $40 \mathrm{~mm}$. Tube dalam heat exchanger berfungsi memindahkan fluegass dari hasil pembakaran kayu, berdiameter $0.033 \mathrm{~m}$ dan panjang $1 \mathrm{~m}$ dengan jumlah 9 pipa. Shell pada heat exchanger berdimensi $0.5 \mathrm{~m}$ $\times 0.3 \mathrm{~m} \times 1 \mathrm{~m}$ terdapat 2 bagian, pertama berfungsi inlet udara lingkungan terletak di bagian bawah tiap dindimg heat exchanger berdiameter $0.036 \mathrm{~m}$ sebanyak 12, dan bagian kedua terletak bagian atas berfungsi meneruskan udara panas ke ruang pengering dengan dimensi $0.28 \mathrm{~m} \times 0.076 \mathrm{~m} \times 0.6 \mathrm{~m}$.
Tiap sisi heat exchanger dipasangkan insulasi berbahan glasswoll ketebalan $40 \mathrm{~mm}$.

5. Cerobong outlet ruang pengering berbentuk kotak dengan dimensi $0.19 \mathrm{~m} \times 0.142 \mathrm{~m} \times 0.7 \mathrm{~m}$ berfungsi untuk menciptakan efek cerobong sehingga terjadi sirkulasi udara pada ruang pengering.

\section{Metode Pengujian}

Metode pengujian dilakukan 2 tahap yaitu; tahap pertama: pengujian tanpa bahan bertujuan untuk mengetahui fungsi alat yang telah dirancang bekerja dengan baik atau tidak. Tahap kedua: pengujian uji kinerja alat pengering untuk mengeringkan biji kopi arabika berkapasitas $5 \mathrm{~kg}$ dengan ketebalan tumpukan 5 $\mathrm{cm}$, dilakukan sebanyak dua kali. Sebagai pembanding dilakukan metode penjemuran langsung dengan produk $2 \mathrm{~kg}$ biji kopi arabika.

Parameter pengukuran meliputi: suhu, kecepatan udara, radiasi surya, massa kayu bakar, dan kadar air biji kopi. Suhu yang diukur adalah suhu udara pada bak, ruang pengering, plenum, outlet kolektor surya, outlet heat excahnger, suhu tungku, outlet cerobong pada ruang dan suhu lingkungan. Pengukuran suhu diukur dengan menggunakan termokopel tipe $\mathrm{K}$ yang dihubungkan pada perangkat data akuisisi. Kecepatan udara diukur dengan anemometer pada ruang outlet kolektor, outlet heat excahnger, outlet cerobong ruang pengering dan kecepatan angin lingkungan. Radiasi surya diukur dengan pyranometer tipe MS-401 dan jumlah bahan bakar pada tungku selama proses pengeringan diukur dengan timbangan sebelum pembakaran. Pengambilan data dilakukan secara periodik yaitu setiap 15 menit sekali selama proses pengeringan.

\section{Analisis Uji Performansi Alat}

Parameter untuk menganalisis uji kinerja alat dijabar sebagai berikut :

1. Pengukuran kadar air biji kopi arabika dilakukan sebelum dan setelah pengeringan. Penentuan mengetahui penurunan kadar air selama proses pengeringan dilakukan pengukuran data penurunan kadar air setiap 1 jam pada 3 cawan sampel dengan tinggi tumpukan kopi $5 \mathrm{~cm}$, menggunakan metode oven pada suhu $105^{\circ} \mathrm{C} \pm 1^{\circ} \mathrm{C}$ selama $16 \mathrm{jam} \pm 1 \mathrm{jam}$ (SNI 2008). Kadar air dihitung dengan persamaan (2).

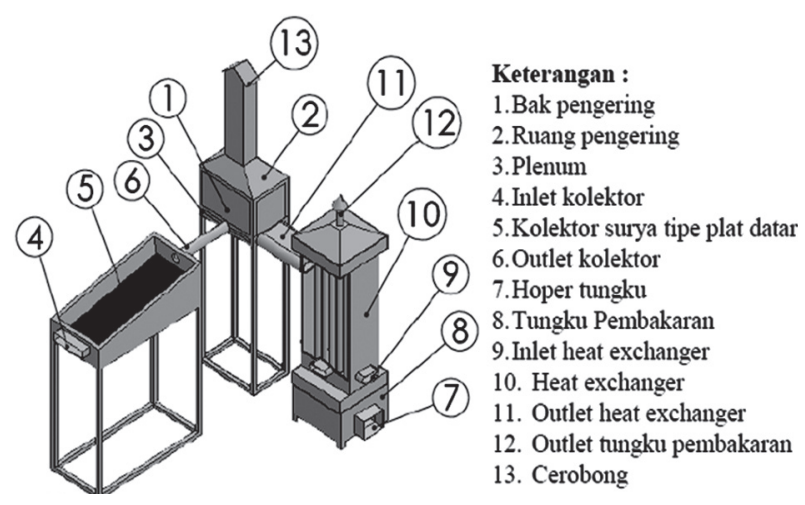

Gambar 1. Alat pengering hybrid. 
$m=\frac{W m}{W d+W m} 100 \%$

dimana $\mathrm{m}$ adalah kadar air basis basah (\%bb), $\mathrm{W}_{\mathrm{m}}$ adalah berat air (gram), $W_{d}$ adalah berat padatan (gram).

2. Laju pengeringan (LP) adalah perubahan kadar air dari bahan per satuan waktu ditentukan dengan persamaan berikut:

$L P=\frac{M_{2}-M_{1}}{\Delta t}$

dimana LP adalah laju pengeringan (\%bk/jam), $M_{1}$ adalah kadar air awal bahan (\%bk), $M_{2}$ adalah kadar air akhir bahan (\%bk), $\Delta t$ adalah waktu pengeringan.

3. Massa air yang diuapkan dari produk selama proses pengeringan dihitung persamaan (4):

$m_{0}=\left(1-\frac{100-m_{i}}{100-m_{f}}\right) \times m_{u}$

dimana $m_{0}$ adalah massa air yang menguap $(\mathrm{kg})$, $m_{i}$ adalah kadar air awal $(\% \mathrm{bb}) m_{f}$ adalah kadar air akhir (\%bb), $m_{u}$ adalah massa awal bahan $(\mathrm{kg})$.

4. Konsumsi Energi Spesifik (KES) merupakan energi yang habis terpakai selama proses pengeringan untuk menguapkan per kilogram $(\mathrm{kg})$ uap air pada produk, ditentukan dengan persamaan (5). Energi yang digunakan selama pengeringan bersumber dari Hybrid (kombinasi) energi surya dan energi biomassa.

$\mathrm{KES}=\frac{Q_{s}+Q_{b}}{m_{o}}$

Jumlah iradiasi surya yang tiba ke kolektor surya $\left(Q_{s}\right)$ dapat ditentukan dari integrasi iradiasi.

$Q_{s}=\int \operatorname{Ih} \times A_{c} d t$

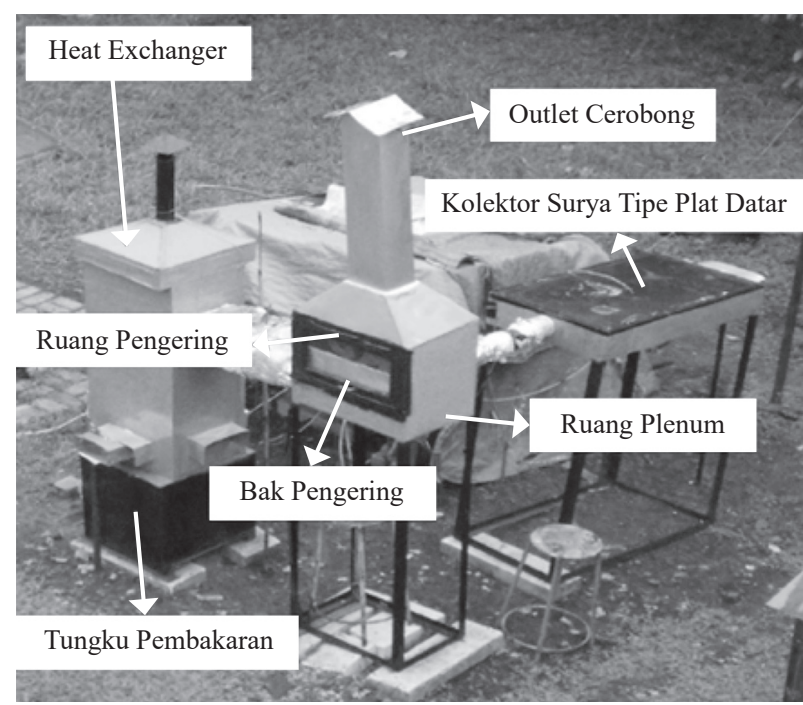

Gambar 2. Alat pengering hybrid efek cerobong tipe bak. yang dilakukan secara numerik menggunakan metode Simpson, dimana $I_{h}$, adalah iradiasi surya sesaat $\left(\mathrm{W} / \mathrm{m}^{2}\right), A_{c}$ adalah luas permukaan koletor $\left(\mathrm{m}^{2}\right)$.

Energi biomassa $\left(Q_{b}\right)$ yang digunakan sebagai sumber panas dari hasil pembakaran langsung berupa kayu rambutan. Nilai kalor kayu rambutan $\left(H_{b b}\right)$ sebesar sebesar $3786 \mathrm{kal} / \mathrm{gram}$ diukur menggunakan bomb calorimeter Parr 6200. Jumlah energi biomassa dapat ditentukan dengan menggunakan persamaan berikut :

$Q_{b}=m_{b b} h_{b b}$

dimana $m_{b b}$ adalah massa kayu bakar $(\mathrm{kg})$ dan $H_{b b}$ adalah nilai kalor $(\mathrm{kJ} / \mathrm{kg})$.

\section{Hasil dan Pembahasan}

\section{Desain Alat Pengering Hybrid}

Alat pengering hybrid dengan efek cerebong tipe bak telah didisain dan difabrikasi pada skala percobaan, seperti tampak pada Gambar 2.

Skema kerja alat pengering hybrid disajikan pada Gambar 3 terdiri dari beberapa bagian utama yaitu; ruang pengering, kolektor surya, dan tungku dan heat exchanger. Biji kopi dikeringkan di dalam bak pengering menggunakan udara panas bersumber baik dari kolektor surya maupun heat exchanger. Kolektor surya digunakan pada pagi sampai siang hari saat surya bersinar, dan jika tidak ada sinar surya maka digunakan tungku pembakaran. Pada siang hari udara lingkungan dipanaskan oleh kolektor kemudian disalurkan ke plenum menuju ruang pengering. Pada malam hari udara panas dialirkan melalui heat exchanger dengan sumber pemanas dari pembakaran kayu di dalam tungku. Udara panas di dalam plenum selanjutnya digunakan untuk mengeringkan biji kopi. Akibat dari tarikan udara di dalam cerobong, maka uap air yang dikeluarkan biji kopi selama proses pengeringan dapat dikeluarkan ke lingkungan melewati cerobong.

\section{Pengujian tanpa bahan}

Pengujian tanpa bahan adalah percobaan alat pengering hybrid tanpa bahan dilaksanakan pada tanggal 03 Maret 2018. Data sebaran suhu dan radiasi surya pada pengujian tanpa bahan ditunjukkan pada Gambar 4.

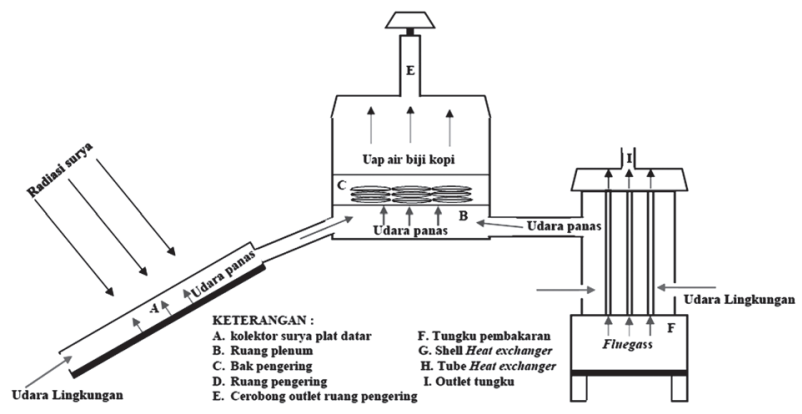

Gambar 3. Skema mekanisme kerja alat. 
Gambar 4 memperlihatkan data radiasi surya dari pukul 08:00-13:00 WIB yang berfluktuatif besaran rata-rata radiasi surya $524 \mathrm{~W} / \mathrm{m}^{2}$. Kolektor surya dapat menaikkan suhu udara pengering dari $30.4^{\circ} \mathrm{C}$ menjadi $46.3^{\circ} \mathrm{C}$. Selama proses tersebut diperoleh suhu udara rata-rata pada pada plenum, bak, ruang pengering, dan outlet cerobong ruang pengering, berturut-turut sebesar $41.3^{\circ} \mathrm{C}, 39.5^{\circ} \mathrm{C}, 37.9^{\circ} \mathrm{C}$, dan $35.4^{\circ} \mathrm{C}$. Untuk mempertahankan suhu udara pengering maka pada saat mendung (pukul 13:45 WIB) tungku pembakaran biomassa dinyalakan, dengan pengumpanan biomassa (kayu) 0.5 -1 kg setiap 45-90 menit seperti tampak pada Gambar 5. Pengumpanan seperti ini setara dengan kira-kira $3 \mathrm{~kW}$ termal. Jika dilihat dari peningkatan suhu di heat exchanger (kira-kira $87^{\circ} \mathrm{C}$ ) maka nampaknya terdapat kehilangan panas yang cukup besar pada tungku.

Pada pukul 14:00-01:00 WIB peningkatan suhu udara rata-rata pada outlet heat exchanger, plenum, bak, ruang pengering dan outlet cerobong ruang pengering berturut-turut $87.1^{\circ} \mathrm{C}, 67.4^{\circ} \mathrm{C}, 60.3^{\circ} \mathrm{C}, 58.3^{\circ} \mathrm{C}$, dan $55.1^{\circ} \mathrm{C}$ dengan suhu lingkungan $26.9^{\circ} \mathrm{C}$. Kondisi ini menunjukkan suhu udara pada ruang pengering berfluktuasi sangat dipengaruhi pengumpanan kayu bakar. Perubahan suhu udara pada ruang pengering yang sejalan dengan perubahan suhu kolektor surya atau heat exchanger menunjukkan bahwa aliran udara dengan efek cerobong telah berjalan dengan baik. Selama percobaan dari pagi hingga malam hari diperoleh rata-rata suhu ruang pengering $50.2^{\circ} \mathrm{C}$ dan $\mathrm{RH}$ ruang pengering $37.42 \%$. Kondisi suhu dan kelembaban udara berpotensi digunakan untuk mengeringkan biji kopi secara baik.

\section{Pengujian dengan Bahan}

Pengujian alat pengering hybrid menggunakan biji kopi arabika dilakukan sebanyak dua kali percobaan P1 dan P2 dilaksanakan pada tanggal 09-22 Maret 2018. Data sebaran hasil pengamatan seperti ditunjukkan pada Gambar 6 dan 7.

Gambar 6 dan Gambar 7 menunjukkan perubahan suhu udara dan distribusi suhu terhadap waktu memiliki pola yang sama dengan tanpa beban. Suhu udara ruang pengering pada siang hari menerima panas hasil penyerapan radiasi surya oleh kolektor surya tiap percobaan $\mathrm{P} 1$ dan $\mathrm{P} 2$ berturut-turut berkisar $27.8-38.4^{\circ} \mathrm{C}$ dan $27.4-37.6^{\circ} \mathrm{C}$ belum mencapai suhu yang diinginkan. Penggunaan tungku sebagai pemanas tambahan berbahan bakar kayu bakar dari sore hingga malam hari dapat mempertahankan suhu ruang pengering pada percobaan $\mathrm{P} 1$ dan $\mathrm{P} 2$ berturut-turut dengan kisaran $38.4-60.9^{\circ} \mathrm{C}$ dan $37.6-58.3^{\circ} \mathrm{C}$. Perubahan suhu ruang

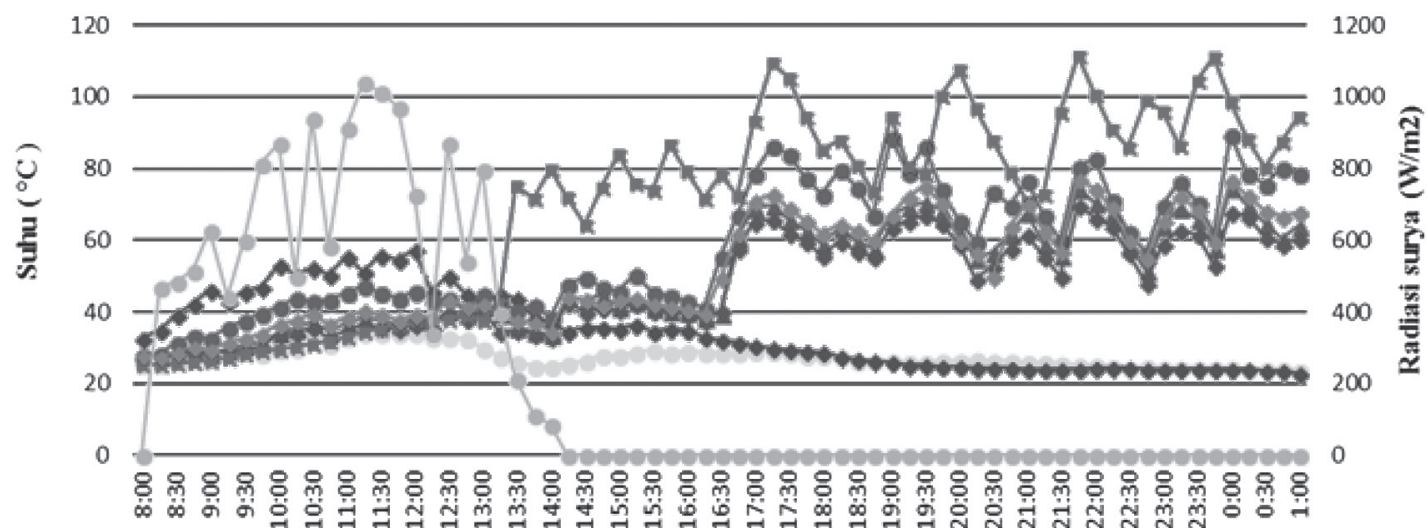

Waktu (WIB)

$$
\begin{aligned}
& \text { Suhu lingkungan }\left({ }^{\circ} \mathrm{C}\right) \\
& - \text { Suhu plenum( }\left({ }^{\circ}\right) \\
& \left.- \text { Suhu outlet cerobong ruang pengering( }{ }^{\circ} \mathrm{C}\right) \\
& - \text { Suhu bak ( }\left({ }^{\circ} \mathrm{C}\right)
\end{aligned}
$$

$=$ - Suhu outlet kolektor $\left({ }^{\circ} \mathrm{C}\right)$

- - Suhu ruang pengering( $\mathrm{C}$ )

- Suhu outlet HE( $\left.{ }^{\circ} \mathrm{C}\right)$

$\rightarrow-$ radiasi surya $(\mathrm{w} / \mathrm{m} 2)$

Gambar 4. Profil suhu alat pengering pada pengujian tanpa bahan.

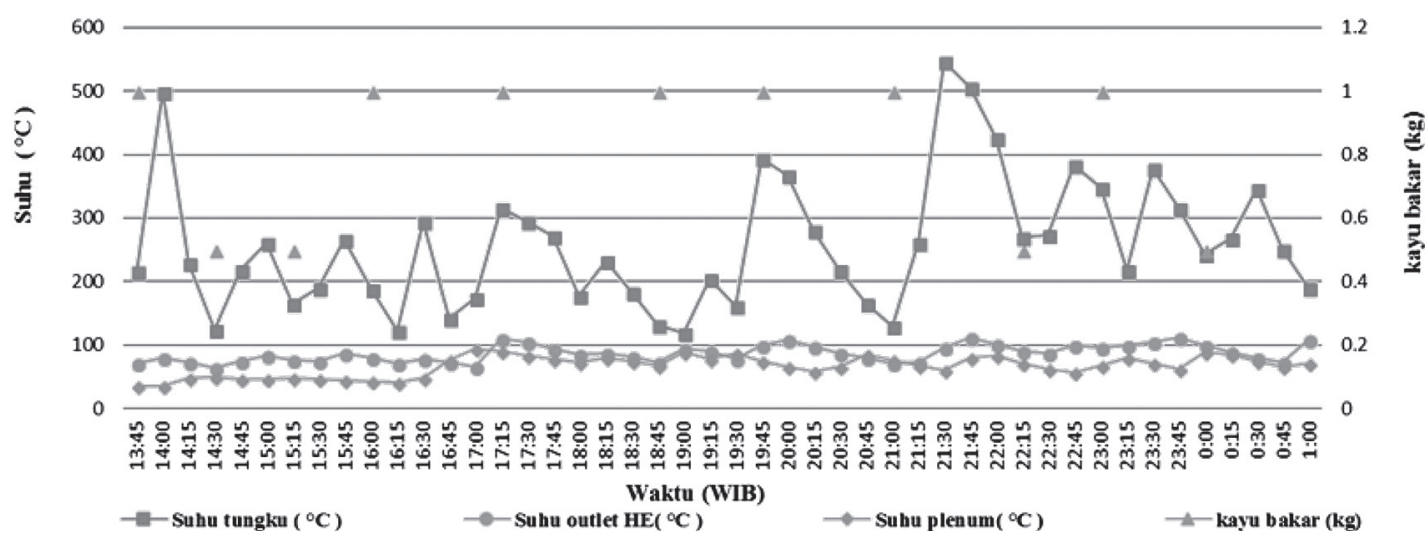

Gambar 5. Profil pengumpanan kayu bakar dan suhu pemanas tambahan pada pengujian tanpa beban. 
pengering pada kondisi siang hari percobaan P1 dan P2 dipengaruhi oleh radiasi surya. Sementara itu perubahan suhu ruang pengering kondisi malam hari ditentukan oleh besarnya dari jumlah bahan kayu bakar. Secara keseluruhan, nilai rata-rata suhu pada percobaan P1 dan P2 tersaji Tabel 1.

Dari Tabel 1 terlihat suhu udara rata-rata plenum pada percobaan $\mathrm{P} 1$ dan $\mathrm{P} 2$ yakni berturut-turut sebesar $61.2^{\circ} \mathrm{C}$ dan $59.8^{\circ} \mathrm{C}$ yang tinggi berpengaruh terhadap waktu pengeringan. Hal ini seperti dilaporkan Graciafernandy et al (2012); Tulliza dan Mursalim (2011) tingginya suhu udara pengering makin besar energi panas yang dibawa dan semakin besar pula perbedaan antara medium pemanas dan produk. Hal ini akan mendorong makin cepatnya proses penguapan air dan waktu pengeringan akan menjadi lebih singkat.

\section{Penurunan Kadar Air terhadap Waktu dan Laju Pengeringan}

Gambar 8 terlihat pola perubahan kadar air tiap percobaan terhadap waktu selama pengeringan memiliki pola yang sama. Kadar air awal biji kopi arabika percobaan KAP1 dan percobaan KAP2 sebelum dikeringkan sebesar $52.5 \%$ bb dan $52.3 \%$ bb0 dikeringkan hingga mencapai kadar air akhir rata-rata sebesar $12.9 \%$ bb dan $12.2 \%$ bb. Dari percobaan menunjukkan kadar air akhir tidak berbeda jauh walaupun kondisi radiasi surya cukup berbeda selama 5 jam pertama.

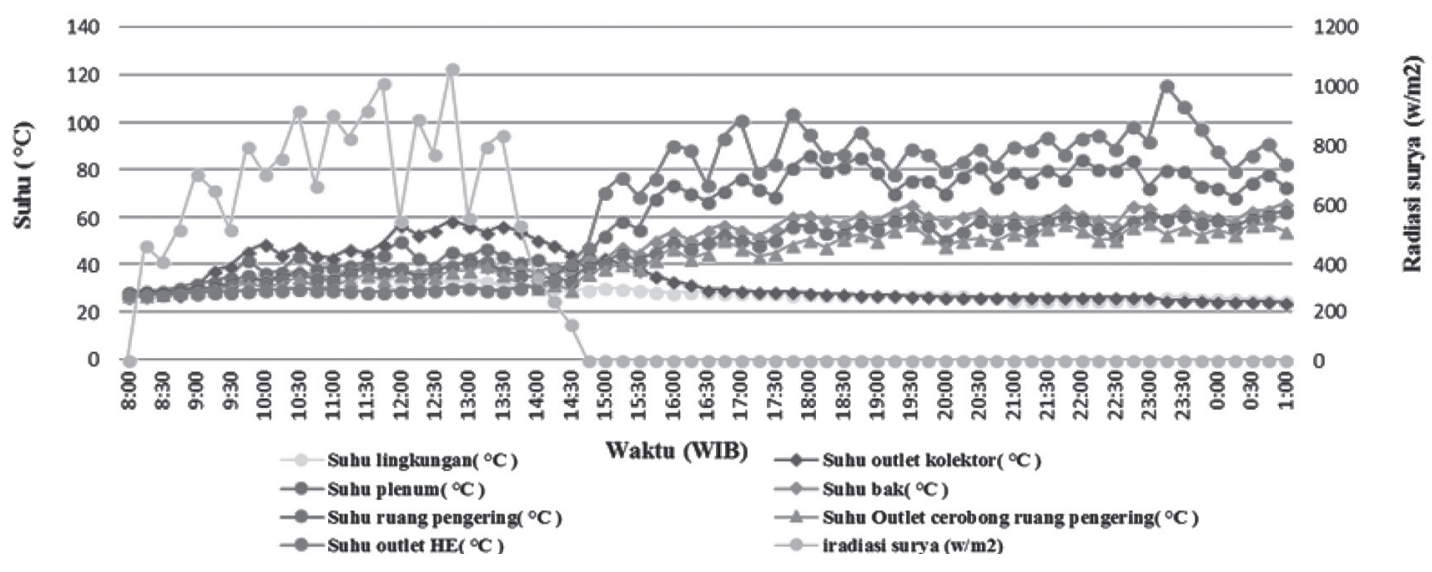

Gambar 6. Profil suhu alat pengering pada percobaan P1.

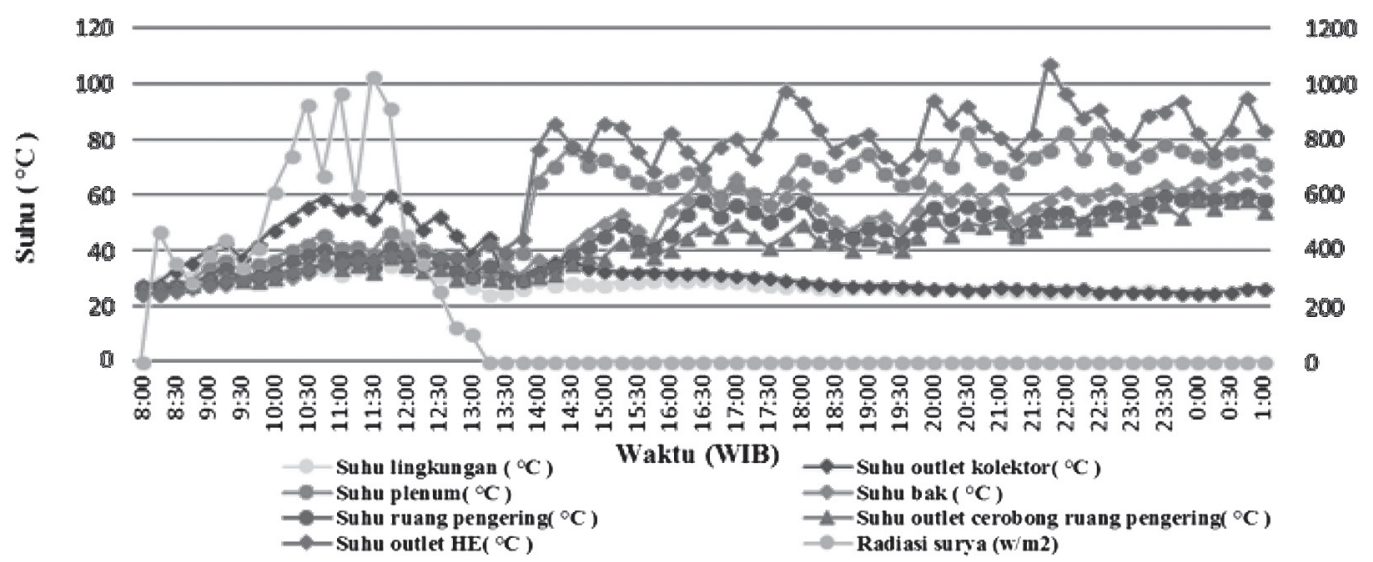

Gambar 7. Profil suhu alat pengering pada percobaan P2.

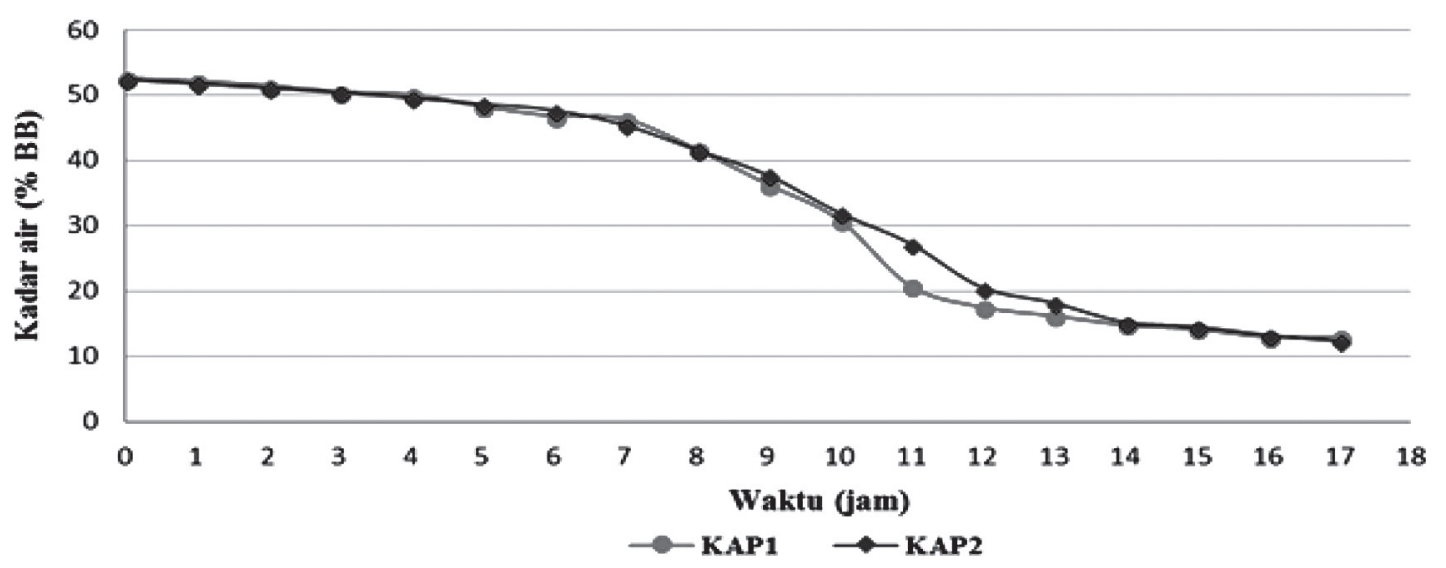

Gambar 8. Grafik Penurunan kadar air biji kopi arabika terhadap waktu. 
Tabel 1. Nilai rata-rata suhu, $\mathrm{RH}$, kecepatan angin, radiasi surya, dan jumlah kayu bakar pada percobaan $\mathrm{P} 1$ dan P2 dengan bahan.

\begin{tabular}{lccc}
\hline Keterangan & Satuan & P1 & P2 \\
\hline Suhu lingkungan & ${ }^{\circ} \mathrm{C}$ & 30 & 29.6 \\
RH lingkungan & $\%$ & 81.4 & 80.3 \\
Kecepatan angin lingkungan & $\mathrm{m} / \mathrm{s}$ & 0.67 & 0.57 \\
Suhu outlet kolektor & ${ }^{\circ} \mathrm{C}$ & 44.8 & 45.2 \\
Kecepatan udara outlet kolektor & $\mathrm{m} / \mathrm{s}$ & 0.26 & 0.24 \\
Suhu plenum & ${ }^{\circ} \mathrm{C}$ & 61.2 & 59.8 \\
Suhu bak & ${ }^{\circ} \mathrm{C}$ & 48.3 & 47.3 \\
Suhu ruang pengering & ${ }^{\circ} \mathrm{C}$ & 46.4 & 45.2 \\
RH ruang pengering & ${ }^{\circ}$ & 51.3 & 58.4 \\
Suhu outlet cerobong ruang pengering & ${ }^{\circ} \mathrm{C}$ & 42.9 & 39.1 \\
Kecepatan udara outlet cerobong ruang pengering & $\mathrm{m} / \mathrm{s}$ & 0.21 & 0.22 \\
Suhu outlet heat exchanger & ${ }^{\circ} \mathrm{C}$ & 87.5 & 79.3 \\
Kecepatan udara outlet heat exchanger & $\mathrm{m} / \mathrm{s}$ & 0.39 & 0.37 \\
Radiasi surya & $\mathrm{W} / \mathrm{m}^{2}$ & 620 & 428 \\
Jumlah kayu bakar & $\mathrm{kg}$ & 7 & 8 \\
\hline
\end{tabular}

Tabel 2. Data analisis uji performasi.

\begin{tabular}{lcccc}
\hline Keterangan & Satuan & P1 & P2 & P3 \\
\hline Massa awal biji kopi arabika & $\mathrm{kg}$ & 5 & 5 & 2.5 \\
Massa akhir biji kopi arabika & $\mathrm{kg}$ & 2.27 & 2.75 & 1.3 \\
Kadar air awal & $\% \mathrm{bb}$ & 52.5 & 52.3 & 52.5 \\
Kadar air akhir & $\% \mathrm{bb}$ & 12.9 & 12.2 & 12.7 \\
Lama Pengeringan & $\mathrm{jam}$ & 16 & 17 & 46 \\
Laju Pengeringan & $\% \mathrm{bk} / \mathrm{jam}$ & 5.9 & 5.6 & 2.01 \\
Total radiasi surya harian & $\mathrm{MJ} / \mathrm{m}^{2}$ & 12.74 & 9.93 & 10.3 \\
Jumlah kayu bakar & $\mathrm{kg}$ & 7 & 8 & \multirow{2}{*}{6.93} \\
Energi surya yang diterima & $\mathrm{MJ}$ & 6.52 & 5.17 & \\
Energi biomassa yang digunakan & $\mathrm{MJ}$ & 110.43 & 126.21 & \\
Penggunaan energi hybrid & $\mathrm{MJ}$ & 117.1 & 131.3 & \multirow{2}{*}{59.4} \\
Konsumsi Energi Spesifik (KES) & MJ/kg uap air & 51.4 & 57.3 & \\
\hline
\end{tabular}

Laju pengeringan pada tiap percobaan cukup meningkat setelah waktu pengeringan 5 jam sehubungan dengan penggunaan bahan bakar biomasa. Bahan bakar biomassa baru digunakan setelah iradiasi surya sudah cukup rendah sehingga, terdapat peningkatan panas setelah pengeringan berlangsung selama 5 jam. Laju pengeringan yang didapatkan pada percobaan KAP1 adalah 5.9\%bk/jam dengan durasi pengeringan 16 jam, sementara itu percobaan KAP2 dengan waktu pengeringan 17 jam diperoleh laju pengeringan sebesar 5.6\%bk/jam. Hasil percobaan KAP1 dan KAP2 menunjukkan kadar air akhir tidak berbeda jauh menandakan bahwa alat pengering hybrid cukup baik dalam mengeringkan biji kopi arabika karena dalam waktu 16-17 jam mampu menurunkan kadar air sesuai target yang diinginkan yaitu sebesar $12.5 \%$ (BSN 2008).

\section{Konsumsi Energi Spesifik Selama Proses Pengeringan}

Konsumsi energi spesifik (KES) merupakan besaran yang menunjukkan tingkat penghematan energi yang dikonsumsi selama proses pengeringan berlangsung. Semakin kecil nilai KES, semakin hemat sistem alat pengering yang didesain. Analisis uji performansi alat pengering hybrid percobaan $\mathrm{P} 1$, percobaan $\mathrm{P} 2$, dan pengujian metode penjemuran P3 tersaji pada Tabel 2 .

Hasil analisis uji performansi pada Tabel 2 menunjukkan besaran dari konsumsi energi spesifik (KES) untuk mengeringkan biji kopi dengan tinggi tumpukan $5 \mathrm{~cm}$ pada percobaan P1 dan P2 secara berturut-turut $51.4 \mathrm{MJ} / \mathrm{kg}$ uap air dan $57.3 \mathrm{MJ} / \mathrm{kg}$ uap air. KES pada percobaan $\mathrm{P} 1$ lebih rendah dari percobaan P2 hal ini dipengaruhi waktu pengeringan, total radiasi yang diterima dan pengunaan kayu bakar. Nilai KES ini masih sangat tinggi. Sebagai contoh hasil penelitian Wulandani (1997) yang mengeringkan biji kopi robusta dengan pengering hybrid berkapasitas 1 ton dengan ketebalan $40 \mathrm{~cm}$ membutuhkan KES sebesar 5.2 $\mathrm{MJ} / \mathrm{kg}$ air yang diuapkan. KES yang rendah pada penelitian tersebut disebabkan oleh beban pengeringan yang cukup besar. Beban pengeringan yang rendah dibandingkan konsumsi energi yang digunakan pada penelitian ini menyebabkan rendahnya KES. Ketika beban pengeringan rendah, panas sensibel yang dimiliki oleh udara lebih banyak meninggalkan sistem pengering bersama aliran. 
Penurunan jumlah pembakaran kayu cukup sulit dilakukan karena suhu pembakaran harus dipertahankan pada suhu yang cukup tinggi untuk menjamin kontinuitas pembakaran. Oleh karena itu, peningkatan beban pengeringan perlu dilakukan. Peningkatan beban sampai sampai $20 \mathrm{~kg}$ dapat menurunkan secara signifikan KES. Namun, hal tersebut akan meningkatkan tebal tumpukan yang mungkin dapat menghambat aliran udara, terutama karena aliran udara pengeringan hanya mengandalkan efek cerobong. Walaupun demikian, penjemuran pada kondisi penelitian berlangsung memberikan KES yang juga cukup tinggi yakni 59.4 MJ/ kg uap air selama 6 hari. Hal ini menunjukkan bahwa walaupun kondisi pengeringan masih jauh dari optimal, metode ini cukup signifikan lebih menguntungkan dari sisi waktu pengeringan dibandingkan penjemuran. Untuk penurunan KES, perlu dilakukan pengujian pengering pada beban pengeringan yang lebih besar. Selain itu insulasi pada bagian tungku pemanas perlu dilakukan dengan menggunakan bahan insulatif yang tahan suhu tinggi dengan ketebalan yang memadai agar kehilangan panasnya lebih rendah.

\section{Simpulan}

Pengembangan desain alat pengering hybrid berenergi surya dan biomassa dengan sistem efek cerobong skala percobaan yang telah dilakukan dan telah di uji. Pada percobaan tanpa bahan menunjukkan pengaliran udara secara efek cerobong sistem terpisah baik dari kolektor surya maupun heat exchanger berjalan dengan baik yang ditunjukkan oleh adanya perubahan suhu ruang pengering. Hasil percobaan dengan bahan suhu udara pada ruang pengering berkisar di siang hari sebesar $27.8-38.4^{\circ} \mathrm{C}$ dan di malam hari sebesar $38.4-60.9^{\circ} \mathrm{C}$. Uji performansi pada alat pengering untuk mengeringkan $5 \mathrm{~kg}$ biji kopi dengan tebal tumpukan 5 $\mathrm{cm}$ jumlah KES pada percobaan P1 dan P2 sebesar $51.4 \mathrm{MJ} / \mathrm{kg}$ uap air dan $57.3 \mathrm{MJ} / \mathrm{kg}$ uap air. KES dari sistem alat pengering hybrid menandakan sudah dapat berfungsi cukup baik untuk mengeringkan biji kopi arabika kadar air akhir sebesar $12.8 \%$ bb dalam waktu 16-17 jam, dibandingkan metode penjemuran membutuhkan waktu 46 jam dengan KES $59.4 \mathrm{MJ} / \mathrm{kg}$ uap air.

\section{Daftar Pustaka}

Al-Naema, M.A. and I. Farkas. 2016. Modelling of a Modular Indirect Natural Convection Solar Dryer. Eurosun 2016. Palma de Mallorca(ES). 11-14 Oktober 2016

[BSN] Badan Standardisasi Nasional. BSN. 2008. Standar Nasional Indonesia Biji Kopi SNI 01-29072008. Jakarta(ID): Badan Standardisasi Nasional.

[BPS] Badan Pusat Statistik. 2012. Provinsi Aceh dalam Angka 2011. Aceh (ID): BPS

[Ditjenbun Kementan] Direktorat Jenderal Perkebunan Kementerian Pertanian. 2012. Pedoman Teknis Penanganan Pasca Panen Kopi. Kementrian Pertanian, Jakarta (ID). Ditjenbun-Kementan.

Graciafernandy, M.A., R. Rahmawati dan L. Buchori. 2012. Pengaruh Suhu Udara Pengering dan Komposisi Zeolit 3A Terhadap Lama Waktu Pengeringan Gabah Pada Bed Dryer. Momentum, Vol.8(2): 6- 10

Holman, J.P. 1990. Heat Transfer. New York (USA): McGraw-Hill.

Ekechukwu, O.V. and B. Norton. 1999. Review of SolarEnergy Drying Systems I: an Overview of Drying Principle and Theory, International Journal of Energy Conversion \& Management, 40, pp 593-613.

Hamni, A., A.G. Ibrahim dan S. Harun. 2014. Implementasi Sistem Gasifikasi untuk Pengeringan Biji Kopi. Jurnal Mechanica. Volume 5, Nomor 1.

Madhlopa, A. and G. Ngwalo. 2007. Solar dryer with thermal storage and biomass-backup heater. Solar Energy. Vol 81(4): 449-462.

Mwithiga, G. and S.N. Kigo. 2006. Performance of a solar dryer with limited sun tracking capability. Journal of Food Engineering. Vol 74 (2): 247-252.

Pangavhane, D.R., R.L. Sawhney and P.N. Sarsavadia. 2002. Design, development and performance testing of a new natural convection solar dryer. Energy. 27(6): 579-590.

Russon, J.K., M.L. Dunn dan F.M. Steele. 2009. Optimization of a Convective Air Flow Solar Food Dryer. International Journal of Food Engineering. 5(1): Article 8.

Tulliza, I.S. dan Mursalim. 2011. Pengeringan Lapis Tipis Biji Jagung Dengan Alat Pengering Sistem Fluidasi. Jurnal Keteknikan Pertanian. Vol 25 (1): 69-72.

Wulandani, D. 1997. Analisis Pengering pada Alat Pengeringan Kopi (Coffea Sp.) Efek Rumah Kaca Berenergi Surya [Tesis]. Bogor (ID): Institut Pertanian Bogor. 